\title{
PERAN AGROINDUSTRI HULU DAN HILIR DALAM PEREKONOMIAN DAN DISTRIBUSI PENDAPATAN DI INDONESIA
}

\author{
Nandika Aisya Pratiwi ${ }^{* 1}$, Harianto**), dan Arief Daryanto ${ }^{* * *}$ \\ *) Program Studi Agribisnis, Sekolah Pascasarjana, Institut Pertanian Bogor \\ Jl. Raya Dramaga, Gedung Sekolah Pascasarjana IPB, Kampus IPB Dramaga 16680 \\ ${ }^{* *}$ Departemen Agribisnis, Fakultas Ekonomi dan Manajemen, Institut Pertanian Bogor \\ Jl. Kamper Wing 2 Level 5, Kampus IPB Darmaga Bogor 16680 \\ ${ }^{* * *}$ Sekolah Bisnis, Institut Pertanian Bogor \\ Jl. Raya Pajajaran, Bogor 16151
}

\begin{abstract}
This study aims to analyze the comparison of roles of the upstream and downstream agroindustries on the economy and income distribution of the Indonesian people. The analyzed economic indicators include output, employment, GDP, exports and imports. The data used in this study were from the Data of Social Accounting Matrix (SAM) as the latest data issued by Central Bureau of Statistics in 2008. The roles of upstream and downstream agroindustries were analyzed using accounting multiplier analysis. In the national economy, downstream agroindustry is more instrumental in the creation of output, added value, and imports while upstream agroindustry has a bigger role in the creation of GDP and exports. In terms of people's income distribution, downstream agroindustry creates a more equitable distribution of income both for domestic agriculture and non-agriculture.
\end{abstract}

Keywords: agroindustry, GDP, income distribution, SAM

\begin{abstract}
ABSTRAK
Penelitian ini bertujuan menganalisis perbandingan peran agroindustri hulu dan hilir terhadap perekonomian dan distribusi pendapatan masyarakat Indonesia. Indikator ekonomi yang dianalisis adalah output, ketenagakerjaan, PDB, ekspor dan impor. Data yang digunakan dalam penelitian ini adalah data Sistem Neraca Sosial Ekonomi tahun 2008 sebagai data SNSE terbaru yang diterbitkan oleh Badan Pusat Statistik. Peran agroindustri hulu dan hilir ini akan dianalisis menggunakan analisis pengganda neraca. Dalam perekonomian nasional, agroindustri hilir lebih berperan dalam penciptaan output, nilai tambah dan impor. Sementara agroindustri hulu lebih berperan dalam penciptaan, PDB dan ekspor. Dari sisi distribusi pendapatan masyarakat, agroindustri hilir menciptakan distribusi pendapatan yang lebih merata baik bagi rumah tangga pertanian maupun non pertanian.
\end{abstract}

Kata kunci: agroindustri, PDB, distribusi pendapatan, SNSE

${ }^{1}$ Alamat Korespondensi:

Email: natasaapriana@gmail.com

\section{PENDAHULUAN}

Pertanian merupakan way of life dan sumber kehidupan sebagian besar masyarakat. Sekitar $45 \%$ tenaga kerja tergantung dari sektor pertanian primer. Peranan sektor pertanian selama ini dalam perekonomian nasional secara tradisional kerap hanya dilihat melalui kontribusinya dalam pembentukan Produk Domestik Bruto(PDB), penciptaan kesempatan kerja, peningkatan pendapatan masyarakat dan perolehan devisa. Peranan baru sektor pertanian sekarang ini dapat diletakkan dalam kerangka " $3 F$ contribution in the economy", yaitu food (pangan), feed (pakan) dan fuel (bahan bakar). Dari fungsi tersebut, terlihat bahwa sektor pertanian tidak hanya berkaitan dengan on-farm saja, tetapi juga berkaitan dengan off-farm baik hulu hingga hilir. Hal ini memperlihatkan bahwa sektor pertanian berperan strategis dalam mewujudkan pembangunan secara 
komprehensif sehingga dapat mengurangi tingkat kemiskinan, sekaligus menciptakan pertumbuhan ekonomi dan lapangan pekerjaan (Daryanto, 2009).

Besarnya peranan sektor pertanian termasuk di dalamnya aspek food (pangan), feed (pakan) dan fuel (bahan bakar) menunjukkan bahwa eksistensi sektor pertanian telah mampu menciptkan rantai nilai tambah bisnis yang berasal dari lahan usaha hingga makanan yang siap saji (from farm to table business). Sektor pertanian tidak hanya berkaitan dengan on-farm saja, tetapi juga berkaitan dengan off-farm baik hulu hingga hilir. Hal ini memperlihatkan bahwa sektor pertanian berperan strategis dalam mewujudkan pembangunan secara komprehensif sehingga dapat mengurangi tingkat kemiskinan, sekaligus menciptakan pertumbuhan ekonomi dan lapangan pekerjaan (Daryanto, 2009).

Selaras dengan hal tersebut, dalam Rencana Strategis Badan Penelitian dan Pengembangan Pertanian (2010) menyatakan bahwa pada kurun waktu 2010-2014, Kementerian Pertanian telah menetapkan sistem pertanian industrial unggul berkelanjutan berbasis sumber daya lokal untuk meningkatkan kemandirian pangan, nilai tambah, ekspor dan kesejahteraan petani sebagai visi pembangunan pertanian. Hal tersebut dipertegas dengan visi yang dituangkan dalam Strategi Induk Pembangunan Pertanian 2013-2045, yaitu terwujudnya sistem pertanian bioindustri berkelanjutan yang menghasilkan beragam pangan sehat dan produk bernilai tambah tinggi dari sumber daya hayati pertanian dan kelautan tropika. Dalam hal ini, agroindustri merupakan fondasi dasar untuk menciptakan sistem bioindustri berkelanjutan.

Kegiatan pertanian industrial atau yang biasa disebut dengan agroindustri perlu dikembangkan karena kedua sektor ini, yaitu sektor pertanian dan industri memiliki peran yang besar dalam PDB. Menurut Badan Pusat Statistik (BPS) (2013), dalam kurun waktu lima tahun terakhir dapat diketahui bahwa sektor industri pengolahan merupakan sektor yang memiliki pangsa terbesar terhadap PDB sebesar $25,8 \%$ pada tahun $2010 ; 25,71 \%$ pada tahun $2011 ; 25,59 \%$ pada tahun 2012; dan 25,53\% pada tahun 2013. Kemudian, sektor pertanian sebagai sektor dengan pangsa terbesar ketiga dalam PDB setelah sektor perdagangan, hotel, dan restoran. Kontribusi sektor pertanian sebesar 13,16\% pada tahun $2010 ; 12,78 \%$ pada tahun $2011 ; 12,53 \%$ pada tahun 2012, dan 12,26\% pada tahun 2013. Dari data tersebut menunjukkan bahwa sektor pertanian dan sektor industri memiliki peran yang besar dalam pembangunan ekonomi Indonesia.

Keterkaitan antara sektor pertanian dan industri juga ditunjukkan dengan banyaknya industri yang bergerak di subsektor agroindustri. Berdasarkan data BPS (2013) diketahui bahwa industri non migas memiliki kontribusi sebesar 92,62\%. Dari kontribusi industri non migas tersebut, $60,25 \%$ adalah kontribusi dari industri makanan, minuman, dan tembakau; industri tekstil, barang dari kulit dan alas kaki; industri kayu dan produk lainnya; industri produk kertas dan percetakan; serta industri produk pupuk, kimia dan karet. Kelima industri tersebut merupakan industri yang mengandalkan sektor pertanian sebagai bahan bakunya.

Mengingat eratnya keterkaitan antara sektor pertanian dan sektor industri maka paradigma baru dalam pembangunan ekonomi yang berorientasi pada agroindustri merupakan strategi industrialisasi yang tepat bagi Indonesia. Hal tersebut dikarenakan sebagian besar sumber daya berada di sektor pertanian dan sebagian besar penduduk Indonesia masih bergantung pada sektor pertanian. Hasil penelitian Priyarsono et al. (2007) menunjukkan bahwa industri pengolahan berbasis pertanian (agroindustri) merupakan sektor yang akan mendorong pertumbuhan ekonomi nasional yang tinggi terutama agroindustri skala kecil dan menengah. Selain itu dikatakan pula bahwa agroindustri merupakan leading sector bagi pembangunan ekonomi Indonesia. Selaras dengan pertumbuhan industri di dunia, Cardenete et al. (2014) meneliti tentang sektor kunci yang harus dijadikan andalan dalam pembangunan ekonomi di negara Spanyol. Dengan menggunakan data SAM (social accounting matrix) tahun 2000, hasil penelitian menunjukkan bahwa sektor yang tepat dijadikan sebagai sektor kunci adalah sektor peternakan yang berbasis bioindustri karena memiliki keterkaitan ke depan dan ke belakang serta dapat memberikan nilai tambah yang tinggi. Hasil penelitian Pieters (2010) menggunakan SAM tahun 2003 menunjukkan bahwa pertumbuhan sektoral di India tidak merata. Hanya pertumbuhan pertanian yang dapat mengurangi ketimpangan sementara pertumbuhan sektor manufaktur berat dan jasa menimbulkan ketimpangan. Ketimpangan ini disebabkan adanya ketidakmerataan upah yang tidak dapat ditanggung sepenuhnya oleh sektor pertanian sehingga harus ada upaya ekspansi tenaga kerja berketerampilan rendah ke bidang manufaktur mengingat tenaga kerja pertanian adalah tenaga kerja berketerampilan rendah. Oleh 
karena itu, industri pengolahan yang berbasis pertanian menjadi fokus utama pembangunannya. Selanjutnya, Mahmud dan Papadopoulou (2010) meneliti tentang pertumbuhan ekonomi di Bangladesh menggunakan metode Computable General Equilibrium (CGE) yang merupakan perluasan dari kerangka Sistem Neraca Sosial Ekonomi (SNSE). Pangsa sektor pertanian terhadap PDB di Bangladesh mengalami penurunan, sedangkan pangsa sektor manufaktur dan jasa meningkat. Dalam perkembangannya, pertanian dan manufaktur memainkan hubungan yang penting dalam membangun agroindustri di Bangladesh.

Proses industrialisasi di Indonesia telah mengakibatkan perubahan peran sektor pertanian dalam perekonomian Indonesia yang ditunjukkan melalui penurunan proporsi output sektor pertanian terhadap output nasional. Berdasarkan data dari BPS (2013), pangsa sektor pertanian dalam pembentukan PDB nasional telah turun dalam lima dasawarsa ini, berkebalikan dengan sektor industri pengolahan (manufaktur) yang pangsanya terus meningkat. Di sisi lain, sumbangan sektor pertanian terhadap lapangan kerja memang relatif menurun, tetapi penurunannya tidak secepat kenaikan sumbangan sektor industri dalam penyerapan tenaga kerja.

Mengingat adanya gap yang masih cukup besar antara pangsa sektor pertanian terhadap PDB yang semakin menurun dan masih besarnya tenaga kerja yang bekerja di sektor pertanian, maka harus ada upaya gradual untuk menurunkan pangsa tenaga kerja di sektor pertanian. Upaya ini dapat dilakukan melalui peningkatan aktivitas off-farm, yaitu melalui pengembangan agroindustri yang melibatkan secara langsung petani dan masyarakat pedesaan. Hal ini merujuk pada beberapa negara di dunia yang juga menerapkan strategi yang sama dalam pertumbuhan ekonomi dan distribusi pendapatannya. Gakuru et al. (2012) melakukan penelitian menggunakan SAM untuk mengetahui distribusi pendapatan di Kenya. Pada penelitian tersebut diketahui bahwa sektor-sektor utama yang berkontribusi bagi pembangunan dan pertumbuhan ekonomi di Kenya adalah manufaktur dan pertanian. Dari sisi distribusi pendapatan, pertumbuhan sektor pertanian dan manufaktur menguntungkan masyarakat perkotaan pedesaan. Dalam hal ini terlihat bahwa agroindustri dapat mengurangi kesenjangan di kota dan di desa. Acharya et al. (2013) mengevaluasi tentang kebijakan restrukturisasi ekonomi melalui agroindustri dan dampaknya pada penduduk miskin di Nepal.
Dengan menggunakan metode SAM, hasil penelitian menunjukkan bahwa kebijakan restrukturisasi ekonomi di Nepal memberikan efek pengganda distribusi pendapatan yang lebih tinggi kepada golongan ekonomi menengah ke atas dan ke bawah.

Bautista (2000) dengan menggunakan multiplier SAM mengamati dampak pembangunan pertanian terhadap distribusi pendapatan di Vietnam. Hasilnya menunjukkan bahwa pembangunan sektor pertanian pengaruhnya lebih besar terhadap rumah tangga yang berpendapatan rendah dibandingkan terhadap rumah tangga yang berpendapatan tinggi baik itu di pedesaan maupun perkotaan. Pertumbuhan pendapatan masyarakat pedesaan secara menyeluruh akan meningkatkan permintaan terhadap produk barang lokal yang diproduksi secara padat karya, juga permintaan terhadap produk agroindustri dan sektor jasa.

Peneliti selanjutnya, yaitu Cogneau dan Robilliard (2000) menggunakan kerangka CGE untuk mengkaji pertumbuhan, distribusi pendapatan dan kemiskinan di Madagaskar. Kerangka SNSE diadopsi ke dalam model CGE untuk pengelompokan rumah tangga. Hasil analisis selanjutnya digunakan untuk menganalisis distribusi pendapatan menggunakan indeks Theil dan analisis kemiskinan menggunakan indeks FosterGreer-Thorbecke (FGT). Dalam menetapkan garis kemiskinan digunakan batasan yang sama dengan Indonesia oleh BPS, yaitu batasan kecukupan pangan sebesar 2100 kkalori/kapita/bulan dan kebutuhan minimum untuk pakaian dan perumahan. Hasil analisis menunjukkan kebijakan menetapkan upah secara formal dan meningkatkan deviden akan menurunkan indeks Theil between. Namun, indeks Theil within cenderung meningkat. Artinya, tidak ada kesamaan arah dampak skenario tersebut terhadap distribusi antar kelompok dan dalam kelompok. Kebijakan tersebut juga secara total menurunkan indeks Theil total. Sedangkan kebijakan meningkatkan upah formal dan deviden 10\% akan berdampak meningkatkan indeks kesenjangan tetapi dapat menurunkan indeks kemiskinan. Dengan skenario ini perubahan indeks Theil antar dan dalam kelompok menunjukkan arah yang sama distribusi yang merata.

Selanjutnya, O'Ryan et al. (2003) mengkaji dampak peningkatan produktivitas capital terhadap distribusi pendapatan dan kemiskinan dengan menggunakan kerangka CGE. Sektor produksi didisagregasi kedalam sektor pertanian primer, sektor primer lainnya, sektor 
agroindustri, sektor industri dan sektor -sektor lainnya. Hasil analisis menunjukkan bahwa peningkatan produktivitas kapital di sektor industri menurunkan kesenjangan pendapatan. Populasi rumah tangga kaya memperoleh peningkatan pendapatan yang jauh lebih besar daripada golongan populasi miskin. Sebaliknya kebijakan di sektor pertanian dan agroindustri akan memperbaiki distribusi pendapatan dan kelompok rumah tangga miskin akan memperoleh peningkatan pendapatan yang lebih besar dibandingkan kelompok kaya.

Di Indonesia, Bangun (2012) meneliti tentang peranan sektor-sektor produksi berbasis pertanian dalam perekonomian Indonesia menggunakan pendekatan SNSE 2008 menyatakan bahwa sektor produksi berbasis pertanian yang menjadi prioritas adalah sektor pertanian tanaman pangan, sektor peternakan dan hasil-hasilnya, sektor industri makanan, minuman, dan tembakau serta sektor jasa restoran. Sektor tanaman pangan serta peternakan dan hasil-hasilnya merupakan sektor paling banyak menyerap tenaga kerja di daerah pedesaan. Sektor jasa restoran serta industri makanan, minuman, dan tembakau adalah sektor produksi yang banyak menyerap tenaga kerja nonpertanian yang tersebar di perkotaan. Menggunakan Structural Analysis Path (SPA) diketahui bahwa rumah tangga buruh tani merupakan rumah tangga yang menerima dampak peningkatan pendapatan paling kecil dari rumah tangga lainnya. Rumah tangga pengusaha pertanian dan golongan atas di perkotaan merupakan penerima dampak peningkatan pendapatan yang terbesar untuk setiap stimulus ekonomi pada neraca endogen dan eksogen sektor produksi prioritas.

Dalam kaitannya dengan investasi dan distribusi pendapatan, Hafizrianda (2006) menggunakan indeks Theil untuk mengkaji dampak peningkatan investasi daerah sebesar satu milyar ke masing-masing sektor ekonomi secara terpisah terhadap distribusi pendapatan rumah tangga menggunakan data SNSE Papua tahun 2003. Hasil analisis menunjukkan bahwa dampak peningkatan investasi tersebut berhasil menurunkan kesenjangan pendapatan, meskipun dampaknya sangat kecil.

Apabila dilihat dari sistem agribisnis, agroindustri merupakan bagian (subsistem) agribisnis yang memproses dan mentransformasikan bahan-bahan hasil pertanian menjadi barang-barang setengah jadi yang langsung dapat dikonsumsi dan barang atau bahan hasil produksi industri yang digunakan dalam proses produksi seperti traktor, pupuk, pestisida, mesin peralatan, dan lain-lain. Dari batasan tersebut, agroindustri merupakan subsektor yang luas yang meliputi industri hulu sektor pertanian sampai dengan industri hilir. Industri hulu adalah industri yang memproduksi alat-alat dan mesin pertanian serta industri sarana produksi yang digunakan dalam proses budi daya pertanian. Industri hilir merupakan industri yang mengolah hasil pertanian menjadi bahan baku atau barang yang siap dikonsumsi atau merupakan industri pasca panen dan pengolahan hasil pertanian (Udayana, 2011).

Mengingat pentingnya peran agroindustri hulu dan hilir tersebut maka dalam penelitian ini akan dianalisis perbandingan peran agroindustri hulu dan hilir dalam perekonomian Indonesia jika dilihat dari output, ketenagakerjaan, PDB, ekspor dan impor. Selain itu akan dianalisis pula perbandingan peran agroindustri hulu dan hilir dalam distribusi pendapatan masyarakat Indonesia.

Ruang lingkup dalam penelitian ini adalah mengkaji peran pembangunan agroindustri yang didisagregasi menjadi agroindustri hulu dan hilir dalam perekonomian Indonesia dan distribusi pendapatan masyarakat. Data utama yang digunakan adalah data SNSE tahun 2008. Disagregasi agroindustri hulu dan hilir berdasarkan data Input Output (IO) Indonesia 2008 dan Survei Industri. Sedangkan perekonomian Indonesia yang dimaksud adalah peranan agoindustri terhadap struktur PDB, output, nilai tambah, ekspor, dan impor. Penggolongan data dalam penelitian ini berdasarkan SNSE ukuran $105 \times 105$.

\section{METODE PENELITIAN}

Data-data yang digunakan dalam penelitian ini adalah data sekunder. Data utama yang digunakan adalah data SNSE dan data updating IO tahun 2008 sebagai data SNSE dan IO terakhir yang diterbitakan oleh Badan Pusar Statistik. Selain itu, data-data pendukung yang digunakan antara lain data Indikator Industri, data Statistik Indonesia. Data bersumber dari Badan Pusat Statistik.

Analisis utama dalam neraca SNSE adalah analisis pengganda neraca (accounting multiplier analysis) yang menjelaskan pengaruh yang ditimbulkan oleh stimulus ekonomi dari suatu variabel eksogen terhadap 
variabel endogen yang disajikan dalam format neraca. Dari tabel SNSE, distribusi pendapatan dan pengeluaran neraca endogen dapat dirinci menjadi:

$\begin{array}{ll}\begin{array}{l}\text { Pendapatan faktor } \\ \text { produksi }\end{array} & : \mathrm{Y} 1=\mathrm{T} 13+\mathrm{X} 1 \\ \begin{array}{l}\text { Pendapatan institusi } \\ \text { Pendapatan kegiatan }\end{array} & : \mathrm{Y} 2=\mathrm{T} 21+\mathrm{T} 22+\mathrm{X} 2 \\ \text { produksi } & \\ \begin{array}{l}\text { Pendapatan faktor } \\ \text { produksi }\end{array} & : \mathrm{Y}^{\prime}=\mathrm{T} 33+\mathrm{T} 21+\mathrm{L} 1 \\ \begin{array}{l}\text { Pengeluaran institusi } \\ \text { Pengeluaran kegiatan } \\ \text { produksi }\end{array} & : \mathrm{Y}^{\prime}=\mathrm{T} 3^{\prime}=\mathrm{T} 22+\mathrm{T} 13+\mathrm{T} 32+\mathrm{L} 2 \\ & \end{array}$

Dengan demikian, persamaan dapat dituliskan secara umum menjadi $\mathrm{Y}=\mathrm{T}+\mathrm{X}$, dimana $\mathrm{Y}$ adalah pendapatan/ pengeluaran, $\mathrm{T}$ adalah transaksi, dan $\mathrm{X}$ adalah neraca eksogen. Matriks T sebagai matriks transaksi antarblok di dalam neraca endogen dapat ditulis sebagai berikut:

$$
\mathrm{T}=\left[\begin{array}{ccc}
0 & 0 & T_{13} \\
T_{21} & T_{22} & 0 \\
0 & T_{32} & T_{33}
\end{array}\right]
$$

Matriks transaksi $\mathrm{T}$ menunjukkan adanya transaksi antarneraca seperti T13, T21, T32, dan transaksi dalam neraca sendiri, yaitu T22 dan T33. Selanjutnya jika besarnya kecenderungan rata-rata pengeluaran (Aij) dianggap sebagai perbandingan antara pengeluaran sektor $\mathrm{j}$ untuk sektor ke i dengan total pengeluaran ke $\mathrm{j}$ (Yj) maka dirumuskan Aij = Tij / Yj. Matriks Aij dapat disusun sebagai berikut :

$$
\mathrm{A}_{\mathrm{m}}=\left[\begin{array}{ccc}
0 & 0 & A_{13} \\
A_{21} & A_{22} & 0 \\
0 & A_{32} & A_{33}
\end{array}\right]
$$

Jika persamaan $\mathrm{Y}=\mathrm{T}+\mathrm{X}$ dibagi dengan $\mathrm{Y}$ maka :

$\mathrm{Y} / \mathrm{Y}=\mathrm{T} / \mathrm{Y}+\mathrm{X} / \mathrm{Y}$ oleh karena $\mathrm{A}=\mathrm{T} / \mathrm{Y}$ maka :

$\mathrm{I}=\mathrm{A}+\mathrm{X} / \mathrm{Y}$

(I-A) $\mathrm{Y}=\mathrm{X}$

$\mathrm{Y}=(\mathrm{I}-\mathrm{A})-1 \mathrm{X}$

$\mathrm{Y}=\mathrm{Ma} X$

Dimana $\mathrm{Ma}=(\mathrm{I}-\mathrm{A})-1$ disebut sebagai matriks pengganda neraca (accounting multiplier) dan (I-A)-1 disebut sebagai matriks kebalikan Leontief. Model tersebut menjelaskan bahwa pendapatan neraca endogen (neraca faktor produksi, neraca institusi, dan neraca sektor produksi) yang dinyatakan dalam notasi $Y$ akan berubah sebesar Ma unit akibat adanya perubahan neraca eksogen, dinyatakan dalam notasi X sebesar satu unit. Besarnya Ma ditentukan oleh besaran koefisien multiplier pada matriks (I-A)-1. Analisis pengganda neraca dapat memperlihatkan keterkaitan sektorsektor ekonomi dan informasi mengenai pemerataan pendapatan dan kesempatan kerja masyarakat.

Kemudian, berdasarkan penelitian-penelitian sebelumnya dapat diambil hipotesis bahwa agroindustri hilir akan memberikan kontribusi yang lebih besar pada pertumbuhan ekonomi Indonesia dan juga memberikan distribusi pendapatan yang lebih merata.

\section{HASIL}

\section{Peran Agroindustri Hulu dan Hilir dalam Perekonomian Indonesia}

Untuk mengetahui peran agroindustri hulu dan hilir dalam perekonomian Indonesia, digunakan analisis angka pengganda SNSE. Angka pengganda yang dibahas adalah pengganda output, nilai tambah, dan PDB atas dasar harga berlaku. Arti dari nilai pengganda tersebut adalah apabila diberikan stimulus ekonomi sebesar 1 milyar rupiah ke sektor agroindustri, maka akan meningkatkan total output, nilai tambah, dan PDB sebesar tiap-tiap nilai penggandanya dengan satuan yang sama.

Hasil analisis ditunjukkan pada Tabel 1. Hasil analisis tersebut dapat diketahui bahwa agroindustri hilir lebih berperan dalam penciptaan output yang lebih besar daripada agroindustri hulu. Hasil ini selaras dengan penelitian Supriyati et al. (2006) yang mengatakan bahwa sektor agroindustri lebih peka menciptakan kenaikan output apabila terjadi peningkatan satu satuan permintaan akhir dibandingkan kemampuannya dalam mendorong sektor pertanian sebagai pemasok bahan baku. Satuan permintaan akhir yang dimaksud adalah permintaan konsumen yang menunjukkan besarnya peranan agroindustri hilir sebagai industri yang mampu menciptakan barang-barang siap pakai dan siap jual bagi masyarakat. Dari Tabel 1 dapat diketahui bahwa industri bambu, kayu, dan rotan menduduki peringkat pertama bagi angka pengganda output. Hal ini berarti hilirisasi industri bambu, kayu, dan rotan memiliki kontribusi yang besar pada output perekonomian nasional. Hasil tersebut senada dengan penelitian Negara (2010) dengan menggunakan data IO tahun 1995, 2000 dan 2008 menyebutkan bahwa sektor kehutanan dalam penciptaan output, nilai tambah dan 
penyerapan tenaga kerja nasional relatif kecil dengan subsektor industri kayu memberikan sumbangan lebih besar daripada subsektor kehutanan primer. Selain itu, subsektor kehutanan memiliki kemampuan dalam mendorong sektor-sektor hilirnya yang menggunakan output produksi subsektor kehutanan primer. Selain itu, dari hasil analisis pengganda dan analisis dampak, sektor kehutanan termasuk dalam sektor yang memiliki dampak pengganda besar bagi perekonomian nasional.

Pengganda nilai tambah akan menunjukkan alokasi nilai tambah ke faktor produksi dari masing-masing sektor produksi. Adanya nilai tambah ini menunjukkan adanya tambahan nilai ekonomi dari sektor produksi yang dikembangkan. Nilai tambah yang diciptakan oleh sektor-sektor ekonomi tersebut salah satunya merupakan sumbangan dari faktor produksi tenaga kerja berupa upah dan gaji. Dengan demikian dapat diperoleh informasi mengenai ketenagakerjaan melalui matriks nilai tambah ini. Dari Tabel 1 terlihat bahwa nilai rerata pengganda pada nilai tambah di sektor hilir lebih besar daripada di sektor hulu. Untuk indikator nilai tambah yang menggambarkan kondisi ketenagakerjaan di Indonesia juga terlihat bahwa agroindustri di sektor hilir lebih menyerap banyak tenaga kerja daripada di sektor hulu. Hal ini berarti industri-industri di sektor hilir dapat membuka lapangan pekerjaan yang lebih luas, sehingga dapat dikatakan bahwa agroindustri hilir bersifat padat tenaga kerja.

Industri yang memberikan kontribusi besar pada nilai tambah adalah industri makanan dan minuman. Jika nilai tambah ini merupakan proxy dari ketenagakerjaan di Indonesia maka dengan adanya industri makanan dan minuman ini mampu menyerap tenaga kerja dalam jumlah yang besar. Berdasarkan data dari Kementerian Koordinator Bidang Perekonomian (2015), jenis industri yang menyerap banyak tenaga kerja adalah industri makanan (823,4 ribu), pakaian jadi (473,6 ribu), tekstil (427,1 ribu), karet dan plastik (357,5 ribu), dan pengolahan tembakau (220,7 ribu). Industri makanan dan minuman yang berkembang pesat di Indonesia ini bersifat padat karya karena mampu menyerap tenaga kerja dalam jumlah besar.

Tabel 1. Angka pengganda output, nilai tambah, ekspor, impor, dan PDB agroindustri hulu dan hilir

\begin{tabular}{lccccc}
\hline \multicolumn{1}{c}{ Sektor } & \multicolumn{5}{c}{ Pengganda } \\
\cline { 2 - 5 } & Output & Nilai tambah & Ekspor & Impor & PDB \\
\hline Agroindustri Hulu & 3,86 & 0,00 & 0,65 & 0,00 & 0,00 \\
Alat dan mesin & 7,44 & 4,64 & 0,44 & 0,23 & 4,87 \\
Pupuk dan pestisida & 5,65 & 2,32 & 0,54 & 0,11 & 2,43 \\
Rerata & & & & & \\
Agroindustri Hilir & 5,98 & 3,82 & 0,68 & 0,85 & 3,67 \\
Pengolahan dan pengawetan makanan & 5,93 & 4,86 & 0,68 & 0,18 & 4,04 \\
Makanan lainnya & 6,97 & 4,15 & 0,68 & 0,00 & 0,00 \\
Minuman & 6,26 & 3,37 & 0,68 & 0,00 & 0,00 \\
Rokok & 6,65 & 0,00 & 0,13 & 0,00 & 0,00 \\
Tekstil, pakaian, dan kulit & 8,22 & 0,00 & 0,38 & 0,00 & 0,00 \\
Bambu, kayu, dan rotan & 5,01 & 0,00 & 0,14 & 0,00 & 0,00 \\
Kertas, barang dari kertas dan karton & 6,60 & 5,08 & 0,60 & 0,19 & 4,27 \\
Penggilingan padi & 6,65 & 0,00 & 0,13 & 0,00 & 0,00 \\
Pemintalan & 6,47 & 2,36 & 0,45 & 0,13 & 1,33 \\
Rerata & & & & & \\
Sektor Primer & 6,55 & 4,82 & 5,43 & 0,70 & 0,61 \\
Pertanian tanaman pangan, peternakan, perikanan & 6,09 & 0,00 & 0,00 & 0,11 & 0,00 \\
Pertanian tanaman lainnya, kehutanan, dan perburuan & 6,32 & 2,41 & 2,71 & 0,40 & 0,30 \\
Rerata & & & &
\end{tabular}


Di sektor hulu, industri pupuk dan pestisida memiliki kontribusi yang paling tinggi dalam nilai tambah. Sektor pertanian merupakan sektor utama yang menggunakan output dari industri pupuk dan pestisida. Karena sektor pertanian masih memiliki kontribusi yang besar dalam perekonomian maka keberadaan dan pembangunan industri pupuk dan pestisida ini akan menyerap banyak pekerja. Menurut data dari Central Data Mediatama Indonesia (2014), kebutuhan pupuk baik organik maupun anorganik di Indonesia terus mengalami peningkatan seiring dengan meningkatnya permintaan dari sektor perkebunan terutama perkebunan kelapa sawit, karet, kakao, kopi, tebu, kapas, tembakau, jagung, dan padi. Tahun 2011 kebutuhan pupuk organik mencapai 12,3 juta ton, tahun 2012 meningkat mencapai 12,6 juta ton dan di tahun 2013 mencapai 12,9 juta ton. Hal yang sama juga terjadi pada pupuk anorganik. Kebutuhan pupuk anorganik terbesar adalah pupuk Urea dengan tingkat konsumsi ratarata di atas $70 \%$ sehingga pupuk Urea sangat sensitif terhadap harga dan sering mengalami kelangkaan. Untuk memenuhi kebutuhan pupuk tersebut PT Pupuk Indonesia yang merupakan induk dari BUMN telah menyiapkan investasi sebesar 24 triliun rupiah hingga tiga tahun ke depan untuk membangun empat pabrik pupuk baru dan merevitalisasi pabrik yang sudah tidak efisien. Kinerja perusahaan pupuk BUMN juga terus meningkat, yang terlihat dari suksesnya perusahaan tersebut meningkatkan penjualan. Selain itu, berdasarkan laporan Kementerian Perindustrian (2012b) pertumbuhan industri non migas sebesar 6,5\% hingga triwulan III tahun 2012 didukung oleh kinerja pertumbuhan sebagian besar kelompok industri non migas yang cukup tinggi. Pertumbuhan tertinggi dicapai kelompok industri pupuk, kimia dan barang dari karet sebesar 8,91\%. Kemudian diikuti kelompok industri semen dan barang galian bukan logam sebesar 8,75\%. Kelompok industri makanan, minuman, dan tembakau di urutan berikutnya dengan pertumbuhan $8,22 \%$.

Nilai rerata untuk PDB pada industri sektor hulu adalah 2,43 yang artinya setiap diberikan stimulus ekonomi ke industri sektor hulu sebesar satu milyar rupiah akan meningkatkan pendapatan nasional sebesar 2,43 miliar. Nilai ini lebih besar daripada agroindustri hilir. Hasil penelitian Bautista et al. (1999) menunjukkan bahwa pembangunan industri yang berorientasi terhadap komoditas pertanian lebih tinggi dan signifikan pengaruhnya terhadap kenaikan riil PDB Indonesa dibandingkan dengan pembangunan industri yang berorientasi pada pengolahan makanan. Pengolahan makanan merupakan bagian dari agroindustri hilir, sehingga industri yang memiliki pengaruh riil dan signifikan adalah agroindustri hulu.

Jika dibandingkan dengan sektor primernya, sektor agroindustri hilir memiliki nilai pengganda yang lebih besar dari sisi output. Dari sisi nilai tambah maupun PDB, sektor primer memiliki nilai pengganda yang lebih besar daripada agroindustri hulu dan hilir. Hal ini membuktikan bahwa agroindustri belum mampu menggeser secara utuh peranan sektor primer pertanian dalam kontribusi ekonomi di Indonesia. Baik dari sisi ketenagakerjaan yang dilihat dari pengganda nilai tambah maupun kontribusi PDB terlihat sektor primer masih besar peranannya.

Ekspor dan impor merupakan indikator untuk menunjukkan pertumbuhan ekonomi suatu negara selain PDB, output, dan nilai tambah. Ekspor dan impor ini berhubungan dengan faktor eksternal atau matriks luar negeri dalam kerangka SNSE. Matriks ekspor diketahui dari interaksi kolom luar negeri dan baris sektor produksi. Untuk matriks impor merupakan interaksi kolom sektor produksi dan baris luar negeri. Jika dibandingkan dengan sektor pertanian primer, nilai pengganda ekspor pada agroindustri hulu dan hilir masih lebih besar. Namun, bagi indikator impor nilai pengganda sektor pertanian primer lebih besar daripada agroindustri hulu dan hilir. Dari Tabel 1 diketahui bahwa agroindustri hulu memberikan penciptaan ekspor yang lebih besar daripada hilir. Namun, bagi indikator impor berlaku sebaliknya. Menurut Rachmat (2010), saat ini produk Indonesia sebagian besar dipasarkan masih dalam bentuk bahan mentah sementara Indonesia mengimpor produk olahan dari bahan baku yang sejenis. Kondisi ini tidak menguntungkan karena Indonesia akan kehilangan nilai tambah produk dan pengembangan investasi usaha pengolahan dengan berbagai penggandanya. Hasil ini sesuai dengan hasil analisis pada kerangka SNSE dimana pada agroindustri hulu memiliki pengganda ekspor yang lebih besar karena produk-produk olahan pada agroindustri hilir belum mampu menembus pasaran internasional. Meskipun demikian, secara penciptaan output lebih besar pada agroindustri hilir, namun berdasarkan hasil tersebut terlihat bahwa output yang dihasilkan hanya memenuhi pasar domestik saja. Sementara nilai impor yang tinggi pada agroindustri hilir dikarenakan masih adanya ketergantungan bahan baku dari luar negeri bagi sebagian industri-industri yang berada pada agroindustri hilir. 
Industri pengolahan dan pengawetan makanan memiliki keistimewaan karena selain menduduki peringkat pertama dalam pengganda ekspor juga sekaligus menduduki peringkat pertama dalam pengganda impor. Hal tersebut dapat terjadi karena beberapa bahan baku industri pengolahan dan pengawetan makanan masih bersumber dari bahan-bahan impor. Ketersediaan bahan baku yang bersumber dari sektor primer pertanian ternyata belum dapat terserap sempurna dan belum mampu mencukupi pasar industri dalam negeri. Oleh karena itu, ekspor bahan mentah (raw material) sebaiknya dikurangi agak sektor primer dapat terserap optimal di dalam negeri untuk mendapatkan nilai tambah yang lebih besar. Di samping itu, menurut data BPS (2013) di bidang ekspor, produk makanan olahan termasuk di dalamnya minuman dan tembakau merupakan salah satu dari sepuluh produk ekspor yang memiliki potensi untuk dikembangkan. Selama lima tahun terakhir ekspor makanan olahan Indonesia mengalami pertumbuhan rata-rata $15,6 \%$ per tahun. Selain itu, ekspor makanan olahan Indonesia tumbuh rata-rata sekitar $15,08 \%$ per tahun melampaui pertumbuhan permintaan pasar impor dunia.

\section{Peran Agroindustri Hulu dan Hilir dalam Distribusi Pendapatan di Indonesia}

Kementerian Perindustrian (2012a) menyatakan bahwa tujuan dari pembangunan industri merupakan bagian dari upaya untuk meningkatkan kesejahteraan masyarakat dengan mengacu pada tiga pilar utama yang menjadi komitmen pemerintah, yaitu pro growth, pro job dan pro poor. Komitmen pemerintah tersebut lebih lanjut dijabarkan dalam Trilogi Pembangunan Industri sebagai berikut: pertumbuhan industri melalui pengembangan dan penguatan industri prioritas, pemerataan industri melalui pengembangan dan penguatan industri kecil dan menengah, persebaran industri melalui pengembangan industri unggulan daerah dan kompetensi inti industri daerah

Dari trilogi tersebut terlihat bahwa pemerataan industri juga merupakan fokus dari pemerintah sehingga adanya pembangunan agroindustri ini diharapkan dapat memberikan pemerataan pendapatan bagi masyarakat. Ketimpangan distribusi pendapatan merupakan akibat langsung dari ketimpangan pelaksanaan pembangunan ekonomi. Kemiskinan dan berkembangnya ketidakmerataan distribusi pendapatan merupakan inti permasalahan pembangunan. Masalah distribusi pendapatan adalah suatu ukuran atas pendapatan yang diterima oleh setiap masyarakat. Dengan menggunakan kerangka SNSE tahun 2008 diperoleh angka pengganda distribusi pendapatan agroindustri hulu dan hilir yang selengkapnya pada Tabel 2 .

Berbeda dengan angka pengganda output, nilai tambah, PDB, ekspor dan impor yang dapat menghasilkan nilai lebih besar dari satu, pengganda pendapatan rumah tangga menghasilkan nilai lebih kecil dari satu. Hal ini menunjukkan bahwa pengaruh peningkatan sektor agroindustri akan menghasilkan dampak peningkatan pendapatan sektor produksi maupun tenaga kerja lebih besar dibandingkan pengaruh yang ditransmisikan ke rumah tangga. Sektor agroindustri hilir menghasilkan rerata nilai pengganda yang lebih tinggi daripada sektor agroindustri hulu. Artinya, pengembangan sektor agroindustri hilir akan memberikan pendapatan rumah tangga lebih besar dibandingkan agroindustri hulu. Keberadaan agroindustri di sektor hulu justru membuat ketimpangan pendapatan semakin besar. Hal ini dikarenakan angka pengganda yang dihasilkan memberikan kontribusi yang besar bagi rumah tangga bukan pertanian di perkotaan golongan atas.

Untuk rumah tangga pertanian, baik rumah tangga buruh tani maupun pengusaha pertanian industri yang memberikan kontribusi pendapatan paling besar adalah industri pengolahan dan pengawetan makanan. Seiring dengan pertumbuhan industri pengolahan dan pengawetan makanan, kebutuhan akan tenaga kerja pun meningkat sehingga mampu memberikan kontribusi pendapatan yang besar bagi rumah tangga penyedia bahan baku, yaitu rumah tangga pertanian. Keberadaaan industri pengolahan dan pengawetan makanan ini harus terus dikembangkan mengingat sebaran distribusi pendapatan yang dihasilkan mampu mencapai sektor rumah tangga terkecil, yaitu rumah tangga buruh tani. Perkembangan industri ini selain mampu meningkatkan output domestik yang tinggi ternyata mampu memberikan nilai distribusi pendapatan yang cukup baik. Bahan baku dari kedua industri ini adalah sektor primer pertanian yang banyak mempekerjakan buruh pertanian. Inilah yang menyebabkan perkembangan kedua industri tersebut akan memberikan penghasilan yang lebih besar bagi buruh tani karena kebutuhan akan bahan bakunya semakin banyak. Hasil tersebut senada dengan penelitian Susilowati (2007) yang menyebutkan bahwa dari sisi pemerataan pendapatan rumah tangga, agroindustri makanan memiliki peran yang baik meskipun dari sisi kontribusi dalam perekonomian nasional nilainya lebih rendah dibandingkan agroindustri non makanan. 
Tabel 2. Angka pengganda distribusi pendapatan agroindustri hulu dan hilir

\begin{tabular}{lcccccc}
\hline \multicolumn{1}{c}{ Sektor } & \multicolumn{3}{c}{ A } & \multicolumn{3}{c}{ B } \\
\cline { 2 - 7 } & 1 & 2 & 3 & 4 & 5 & 6 \\
\hline Agroindustri Hulu & & & & & & \\
Alat dan mesin & 0,00 & 0,00 & 0,00 & 0,00 & 0,00 & 0,00 \\
Pupuk dan pestisida & 0,11 & 0,10 & 0,11 & 0,12 & 0,33 & 0,75 \\
Agroindustri Hilir & & & & & & \\
Pengolahan dan pengawetan makanan & 0,96 & 0,76 & 0,10 & 0,22 & 0,29 & 0,14 \\
Makanan lainnya & 0,11 & 0,37 & 0,17 & 0,38 & 0,67 & 0,88 \\
Minuman & 0,00 & 0,00 & 0,00 & 0,00 & 0,00 & 0,00 \\
Rokok & 0,00 & 0,00 & 0,00 & 0,00 & 0,00 & 0,00 \\
Tekstil, pakaian, dan kulit & 0,00 & 0,00 & 0,00 & 0,00 & 0,00 & 0,00 \\
Bambu, kayu, dan rotan & 0,00 & 0,00 & 0,00 & 0,00 & 0,00 & 0,00 \\
Kertas, barang dari kertas dan karton & 0,00 & 0,00 & 0,00 & 0,00 & 0,00 & 0,00 \\
Penggilingan padi & 0,21 & 0,47 & 0,96 & 0,41 & 0,72 & 0,97 \\
Pemintalan & 0,00 & 0,00 & 0,00 & 0,00 & 0,00 & 0,00 \\
Sektor Primer & & & & & & \\
Pertanian tanaman pangan, peternakan, perikanan & 0,13 & 0,20 & 0,39 & 0,13 & 0,26 & 0,36 \\
Pertanian tanaman lainnya, kehutanan dan perburuan & 0,00 & 0,00 & 0,00 & 0,00 & 0,00 & 0,00 \\
\hline
\end{tabular}

Keterangan:

$\mathrm{A}=$ rumah tangga pertanian

$\mathrm{B}=$ rumah tangga bukan pertanian

$1=$ rumah tangga buruh pertanian

$2=$ rumah tangga pengusaha pertanian

$3=$ rumah tangga bukan pertanian di pedesaan golongan rendah

$4=$ rumah tangga bukan pertanian di pedesaan golongan atas

$5=$ rumah tangga bukan pertanian di perkotaan golongan rendah

$6=$ rumah tangga bukan pertanian di perkotaan golongan atas

Bagi rumah tangga bukan pertanian di pedesaan baik golongan atas maupun golongan bawah, industri yang memberikan kontribusi pendapatan terbesar adalah industri penggilingan padi. Industri penggilingan padi nampaknya menjadi peluang bagi masyarakat untuk melaksanakan industrialisasi di pedesaan. Selain itu pembangunan industri penggilingan padi di pedesaan dapat dijadikan alternatif mata pencaharian selain bekerja di sektor primer sebagai petani.

\section{Implikasi Manajerial}

Berdasarkan hasil penelitian, implikasi manajerial yang dapat disarankan antara lain adanya inovasiinovasi produk pada agroindustri hulu sesuai kebutuhan konsumen sehingga mampu menghasilkan penciptaan output yang besar dalam perekonomian. Perlunya permodalan, investasi serta penerapan economic labelling bagi produk-produk agroindustri hilir khususnya industri makanan dan minuman yang sedang berkembang pesat di Indonesia supaya dapat bersaing di pasar internasional sehingga kontribusi agroindustri hilir pada ekspor semakin besar.

\section{KESIMPULAN DAN SARAN}

\section{Kesimpulan}

Dari uraian kajian mengenai peran agroindustri hulu dan hilir dalam perekonomian dan distribusi pendapatan masyarakat Indonesia dapat diambil kesimpulan bahwa dalam perekonomian nasional, agroindustri hilir memberikan penciptaan output dan kesempatan kerja yang besar sedangkan agroindustri hulu memberikan kontribusi pada PDB lebih besar. Pada indikator ekspor, agroindustri hulu berperan lebih besar daripada agroindustri hilir sedangkan untuk impor berlaku sebaliknya.

Baik rumah tangga pertanian maupun rumah tangga nonpertanian, agroindustri hilir lebih berperan dalam memberikan distribusi pendapatan yang lebih merata. Bagi rumah tangga pertanian, industri yang berperan besar adalah industri pengolahan dan pengawetan makanan sedangkan bagi rumah tangga nonpertanian adalah industri penggilingan padi. 


\section{Saran}

Berdasarkan hasil analisis dan kajian, saran yang dapat disampaikan antara lain pentingnya pengembangan industri-industri yang termasuk dalam agroindustri hilir perlu menjadi prioritas pemerintah. Hal ini disebabkan agroindustri hilir memiliki peran yang besar dalam penciptaan output nasional dan juga dapat memberikan distribusi pendapatan yang baik karena dapat menjangkau golongan ekonomi paling bawah, yaitu buruh tani. Selanjutnya, Agroindustri hulu memiliki peran yang besar dalam ekspor, tetapi di sisi lain nilai tambah yang diperoleh Indonesia juga kecil karena produk yang diekspor bukan barang olahan tetapi barang input. Oleh karena itu, hilirisasi produk merupakan solusi untuk mencegah berkurangnya nilai tambah produk. Bagi penelitian selanjutnya, diharapkan dapat mendisagregasi kerangka SNSE dengan lebih rinci menggunakan data terbaru.

\section{DAFTAR PUSTAKA}

Acharya S, Signorelli M, Vojinovic B, Oplotnik ZJ. 2013. Alternative approach to economic restructuring to benefit the poor-sam multipliers analysis as alternative approach. Journal of Scientific Annals of The Alexandru Ioan Cuza Universty of Iasi Economic Science 60(1): 1-20. https://doi.org/10.2478/aicue-2013-0016.

Badan Penelitian dan Pengembangan Pertanian. 2010. Rencana Strategis Badan Penelitian dan Pengembangan Pertanian Tahun 20102014. Jakarta: Kementerian Pertanian Republik Indonesia.

[BPS] Badan Pusat Statistik. 2013. Statistik Indonesia. http://www.bps.go.id. [21 Juni 2014].

[BPS] Badan Pusat Statistik. 2013. Distribusi pembagian pengeluaran per kapita dan indeks Gini 20102013. http://www.bps.go.id. [16 Juni 2015].

[BPS] Badan Pusat Statistik. 2013. Jumlah angkatan kerja, penduduk bekerja, pengangguran, TPAK dan TPT 1986-2013. http://www.bps.go.id. [16 Juni 2015].

Bangun IP. 2012. Peranan sektor-sektor produksi berbasis pertanian dalam perekonomian Indonesia: Pendekatan SNSE Tahun 2008. [Tesis]. Yogyakarta: Universitas Gadjah Mada.

Bautista RM, Robinson S, El Said M. 1999. Alternative industrial developments paths for Indonesia: SAM and CGE Analysis. TMD Discussion Paper
No.42, Washington.

Bautista RM 2000. Agriculture-based development: a SAM perspective on central Vietnam. The Developing Economies 34(1): 112-32.

Cardenete MA, Boulanger P, Delgado MDC, Ferrari E, M'Barek M. 2014. Agri-food and bio-based analysis in the spanish economy using a key factor approach. Journal of RURDS 2(26): 112134.

Central Data Mediatama Indonesia. 2014. Studi potensi bisnis industri pupuk di Indonesia. http://www. cdmione.com.[7 Oktober 2016].

Cogneau D, Robilliard AS. 2000. Growth, Distribution and Poverty in Madagascar: Learning from A Microsimulation Model in General Equilibrium Framework. Trade and Macroeconomic Division, International Food Policy Research Institute, Washington, D.C, USA.

Daryanto A. 2009. Dinamika Daya Saing Industri Peternakan. Bogor : IPB Press.

Gakuru R, Mathenge N. 2012. Poverty, Growth, and Income Distribution in Kenya: A SAM Perspective. Working Paper African Growth and Development Policy (AGRODEP).

Hafizrianda Y. 2006. Dampak sektor pertanian terhadap distribusi pendapatan dan perekonomian Regional Provinsi Papua: suatu model sistem neraca sosial ekonomi [disertasi]. Bogor: Institut Pertanian Bogor.

Kementerian Perindustrian. 2012a. Outlok Industri 2012: Strategi Percepatan dan Perluasan Agroindustri. Jakarta:KementerianPerindustrian Republik Indonesia.

Kementerian Perindustrian. 2012b. Peran sektor Industri dalammendorong pertumbuhan ekonomi nasional. Harian Ekonomi Neraca. http:/www. kemenperin.go.id/artikel/5422/Peran-SektorIndustri-dalam-Mendorong-PertumbuhanEkonomi-Nasional. [12 Oktober 2016]

Kementerian Pertanian. 2013. Strategi Induk Pembangunan Pertanian 2013-2045: Membangun Pertanian Bioindustri Berkelanjutan. Jakarta: Kementerian Pertanian Republik Indonesia.

Mahmud T, Papadopoulou E. 2010. Competitive capacity and export potential of agro-processing industries under the trade liberalization regime in Bangladesh. Asian Journal of Food and AgroIndustry 3(4): 400-419.

Negara K. 2010. Analisis peranan sektor kehutanan dalam perekonomian Indonesia: pendekatan 
input output. [Tesis]. Depok. Universitas Indonesia.

O’Ryan R. Miguel CJ. Miller S, Munasinghe M. 2003. The Role of Agriculture in Poverty Alleviation, IncomeDistribution andEconomic Development: A CGE Analysis for Chile. Agricultural and Development Economics Division (ESA). FAO of the United Nation, Rome.

Pieters J. 2010. Growth and inequality in India : analysis of an extended social accounting matrix. Journal of World Development 3(38): 270-281. https:// doi.org/10.1016/j.worlddev.2009.09.006.

Priyarsono DS, Backe D. 2007. Industri berbasis pertanian: arah pengembangan industri di Indonesia. SOCA 8(3): 256-264.

Rachmat M. 2010. Perspektif pengembangan industri pengolahan pangan di Indonesia. http://www. litbang.pertanian.go.id. [7 Oktober 2016].
Supriyati, Suryani E. 2006. Peranan, peluang dan kendala pengembangan agroindustri di Indonesia. Forum Penelitian Agro Ekonomi 25(2): 92-106

Susilowati SH. 2007. Dampak kebijakan ekonomi di sektor agroindustri terhadap distribusi pendapatan dan kemiskinan di Indonesia. [disertasi]. Bogor: Institut Pertanian Bogor.

Susilowati SH, Sinaga BM, Limbong WH, Erwidodo. 2007. Dampak kebijakan ekonomi di sektor agroindustri terhadap kemiskinan dan distribusi pendapatan rumah tangga di indonesia: analisis simulasi dengan sistem neraca sosial ekonomi. Jurnal Agro Ekonomi 25(1): 11-36. https://doi. org/10.21082/jae.v25n1.2007.11-36.

Udayana IGB. 2011. Peran agroindustri dalam pembangunan pertanian. Singhadwala. Edisi 44. Februari 2011. 